滋賀県立成人病センター附属病院放射線部

○山田茂樹・安井 清 ・ 山口 定 坂本康夫・北林啓太郎・古池孝之 丹保幸廣

増設に伴う業務の増加に対応するため，胸部チェンジ ヤと，2台のモノフィーダを合流させる 3 方向モジュー ルを組み入れたシステムを導入した。このシステムでの 各モジュールの使用状況および，フィルムの流れについ て検討した。

このシステムにより，自現機の処理能力を十分に発揮 することができ，混雑時における業務の流れをスムーズ にし，患者の待ち時間短縮など，日常業務において成果 を発揮している。しかし，フィルムの待機時間，明室の 湿度により極くまれではあるが，スタチックマークが発 生することがあり，今後の課題となっている。

407. 当院におけるティライトシステムの現状について 福井医科大学附属病院放射線部

○池野 徹・早川和也・木戸屋栄次 松下照雄・吉村和彦・田中雅人

吉村浩幸・小室裕冊

当院では自現機直結型レシーブサプライヤを用いたデ イライトシステムおよび自現機直結型フィルム搬送シス テムを導入し，作業能率の合理化・省力化ができた。そ こで業務量の分析と合わせて現状について調查した。レ シーブサプライヤを用いた結果，フィルム処理が一回の 工程ですみ，作業動線も短かく配置してあるため少人数 で作業できる。またカセッテレス搬送システムの導入に よりカセッテ枚数の減少, レシーブマガジンの運搬不要, フィルムの逐次現像ができ，患者サービスの向上と再撮 影時の対応が早くなった。 また六ッ切チェンジャを増設 すれば，単純撮影部門でのカセッテレス化が進み今後の 患者数の増加にも十分対応できると予測した。

\section{8．AOT 用明室タイプオートフィダの開発}

秋田県立脳血管研究センター

○小野寺洋・豊島英仁

富士メディカルシステム株式会社 北村和明

〔目的〕連続撮影済フィルムの明室処理を可能とする AOTレシーブマガジン用オートフィダーを開発し実用 化を計る。

〔結果〕（1)オートフィダI 型，従来のオートフィダに マガジンサポータ，シャッタ，搬送リンク部を増設し AOT 専用とした. (2)オートフィダII型，I 型の若干の構 造的欠点を補うため搬送リンク，マガジンサポー夕，保 護回路，搬送ローラ等増設改良し，フィルム出口に致る
のを自然落下方式から機械的強制搬入方式にし搬送に確 実性を持たせる改造を行った。これにより(1) AOT 連続 撮影後の明室処理が可能となった。(2)本装置により明室 システム全体の完成に大きく関与した。(3)AOT 以外機 種，他機種の増設も可能である.

409. サクラ SDRS-5 の使用経験

獨協医科大学越谷病院放射線部

○岩崎幸男・竹花弘充・伊沢康幸 丹野勝弘・平山秀樹・椎名徳彦 山本純郎・別所啓子・川羽田秀幸 林 庸行

1984年 6 月開院よりサクラ SD レシーブサプライヤと GX300 との組合せによるデーライトシステムを導入し， 性能，フィルム処理状況，問題点等について検討した。 SDRS3 を 2 ケ月半使用後, SDRS5 と交換したので両機 種の性能比較を行った. SDRS5 は 5 個のサプライチャ ンネル数と同一サイズ異種フィルムを 3 種類まで選択で きるのが大きな特徴である。

当放射線部における暗室処理と SDRS5 との処理枚数 を比較した結果，暗室でのカセッテ処理の減少等により， 暗室業務の軽減（SDPによる完全明室化等）が図られ SDRS5 の有用性を認めた。機構的に改良を望む点など $2 \sim 3$ あるが良好な結果が得られた。

\section{座長集約}

撮影業務の歴史の中で，暗室処理業務の占める割合は 非常に大きなものであったが，昭和30年代後半の自動現 像機の開発に始まり，40年代後半にはサプライヤとレシ ーバの分離したディライトシステムの開発，そして50年 代後半になりサプライヤ，レシーバが一体化され自動現 像機にも直結した multi type が普及し始めたことによ って，暗室処理業務は著しく軽減され工数・技能の節約， 労働環境の改善等につながり，いわゆる省力化が図られ てきた。

このセッションでは, デイライトシステムの使用経験 を主にして 6 題の発表が行われた。

演題404は, 高温多湿な地域性を考慮し 6 台の除湿機と 2 台の冷却機を設置してシステムの作動性について検討 を行った。除湿機を設置することで24時間平均湿度 $73 \%$ が $63 \%$ となり良好な作動性が得られたと報告しているが， 除湿機の有，無によるトラブル比較，また湿度何\%以上 でトラブルが発生するかの報告がなされたならば参考に なろう。

演題405は, 既設の暗室を改良しフィルム搬送システム を設置した報告で，既存暗室にシステム導入を検討中の 